\title{
Heavy metal contamination of Pleuronectiformes species from Sinop coasts of the Black Sea
}

\section{Contaminación por metales pesados de especies de pleuronectiformes de la costa de Sinop en el Mar Negro.}

\author{
Levent Bat ${ }^{1 *}$, Fatih Şahin ${ }^{1}$, Ayşah Öztekin ${ }^{1}$ \\ ${ }^{1}$ Sinop University Fisheries Faculty, Department of Hydrobiology, 57000 Sinop, Turkey \\ *corresponding author e-mail: leventbat@gmail.com
}

\begin{abstract}
In the Turkish Black Sea coasts fish is particularly consumed because of high protein supplies, essential amino acids, vitamin, and mineral content. Fish are exposed to contaminants such as heavy metals in polluted waters. The aims of the study are to determine heavy metals in Pleuronectiformes species from Sinop coasts of the Black Sea and determine the health risks due to the consumption of contaminated fish. Pleuronectiformes species Scophthalmus maximus (Linnaeus, 1758) belonging to Scophthalmidae family, Arnoglossus laterna (Walbaum, 1792) belonging to Bothidae family and Pegusa lascaris (Risso, 1810) belonging to Soleidae family were collected from Sinop coasts of the Black Sea in fishing season of 2016. Heavy metals $(\mathrm{Hg}, \mathrm{Cd}, \mathrm{Pb}, \mathrm{Cu}$ and $\mathrm{Zn}$ ) in edible tissues were determined by ICP-MS (Agilent 7700x). The limit values given by the international and national organizations did not exceed in the muscle tissues of turbot, Mediterranean scald fish and sand sole. Overall $\mathrm{Zn}$ was detected in higher concentrations in all species followed by $\mathrm{Cu}, \mathrm{Pb}, \mathrm{Hg}$ and $\mathrm{Cd}$. The results obtained from the analyses of the maximum levels of the metals except $\mathrm{Hg}$ were found in turbot. The highest $\mathrm{Hg}\left(0.021 \pm 0.007 \mu \mathrm{g} \mathrm{g}^{-1}\right.$ wet wt.) was found in sand sole. However, the high amounts of $\mathrm{Cd}, \mathrm{Pb}, \mathrm{Cu}$ and $\mathrm{Zn}$ in turbot were $0.011 \pm 0.004,0.07 \pm 0.005,1.32 \pm 0.28$ and $14 \pm 3 \mu \mathrm{g} \mathrm{g}^{-1}$ wet wt., respectively. The EDIs and EWIs of the metals were estimated taking into account the mean of metal in all fish samples and the mean consumption of fish per day/week for adults. These results are normally significantly lower than the recommended values of FAO/WHO. Estimated HIs of all the considered metals were
\end{abstract}


below the value of 1 , therefore the metals in fish samples do not toxic any apparent threat to the population and these fishes are healthy for consumption.

Keywords: Scophthalmus maximus, Arnoglossus laterna, Pegusa lascaris, heavy metals, Black Sea

\section{RESUMEN}

En las costas turcas del Mar Negro, el pescado se consume especialmente debido a los altos contenidos de proteínas, aminoácidos esenciales, vitaminas y contenido mineral. Los peces están expuestos a contaminantes tales como metales pesados en aguas contaminadas. Los objetivos del estudio son determinar los metales pesados en las especies Pleuronectiformes de las costas Sinop del Mar Negro y determinar los riesgos para la salud debido al consumo de pescado contaminado. Las especies de Pleuronectiformes Scophthalmus maximus (Linnaeus, 1758) pertenecientes a la familia Scophthalmidae, Arnoglossus laterna (Walbaum, 1792) pertenecientes a la familia Bothidae y Pegusa lascaris (Risso, 1810) pertenecientes a la familia Soleidae se recolectaron de las costas Sinop del Mar Negro en la temporada de pesca de 2016. Los metales pesados $(\mathrm{Hg}, \mathrm{Cd}, \mathrm{Pb}, \mathrm{Cu}$ y $\mathrm{Zn}$ ) en tejidos comestibles se determinaron mediante ICP-MS (Agilent 7700x). Los valores límite dados por las organizaciones internacionales y nacionales no superaron en los tejidos musculares de rodaballo, pez escaldado del Mediterráneo y lenguado de arena. En general, se detectó Zn en concentraciones más altas en todas las especies, seguido de $\mathrm{Cu}, \mathrm{Pb}, \mathrm{Hg}$ y $\mathrm{Cd}$. Los resultados obtenidos de los análisis de los niveles máximos de los metales, excepto $\mathrm{Hg}$, se encontraron en el rodaballo. El $\mathrm{Hg}$ más alto $(0.021 \pm 0.007 \mu \mathrm{g}$ g-1 de peso húmedo) se encontró en la suela de arena. Sin embargo, las altas cantidades de $\mathrm{Cd}, \mathrm{Pb}, \mathrm{Cu}$ y $\mathrm{Zn}$ en el rodaballo fueron $0.011 \pm 0.004,0.07 \pm 0.005,1.32 \pm 0.28$ y $14 \pm 3 \mu \mathrm{g} g-1$ de peso húmedo, respectivamente. Los EDI y los EWI de los metales se calcularon teniendo en cuenta la media del metal en todas las muestras de pescado y el consumo medio de pescado por día / semana para los adultos. Estos resultados son normalmente significativamente más bajos que los valores recomendados por la FAO / OMS. El valor estimado de HI de todos los metales considerados fue inferior al valor de 1 , por lo que los metales en las muestras de peces no son tóxicos para ninguna amenaza aparente para la población y estos peces son saludables para el consumo.

Palabras clave: Scophthalmus maximus, Arnoglossus laterna, Pegusa lascaris, metales pesados, Mar Negro 


\section{INTRODUCTION}

The pollution of marine coastal environment by chemical contaminants in particular heavy metals has happened one of the most likely critical ecological issues of the century. As a result of the heavy metals transport from industrial areas into the environment and their chemical persistence, many marine ecosystems like the Black Sea are faced with spatially or temporally alarming high levels of heavy metals (Bat et al. 2009, Bat 2014, Bat and Özkan 2015, Bat et al. 2018a). Some of essential heavy metals are biodegradable and rapidly decay into harmless or less harmful forms, while nonessentials are non-biodegradable and remain dangerous for a long time. Now, there is a growing concern universal over the indiscriminate use of such heavy metals, causing major environmental damage and toxicity risk to marine organisms (Bat 2017; Bat and Arici 2018). Thus, ecological damage of the environment caused by anthropogenic factors as well as the presence of heavy metals may affect people (Bat et al. 2018b). Heavy metals tend to accumulate in advanced organisms through bio-magnification effects in the food chain. Thus they can enter into human body and accumulate in the human tissues to pose chronic toxicity. Chronic assimilation of heavy metals is a known cause of cancer.

The Black Sea has been subjected to major changes induced by human activities. Origins of the Black Sea's contamination problems are varied. Wastes from towns and cities, farms and plants run into the Black Sea; some get directly from the coast, but most flows unrelentingly from the region's major rivers. In recent years, contaminants have been accountable for major impacts on life in marine coastal waters. It may be clearly seen that the Black Sea is one of the world's the very threatened marine ecosystems. In rising environmental regulations, the European Community has concentrated pollution control and support of Marine Strategy Framework Directive. This is principally stated for the Dangerous Substances Directive which has led to European standards for pollutants including heavy metals. Turkey has already let standards for chemicals (Bat et al. 2018a). It is obviously concluded that the circumstances in the Black Sea calls for urgent actions.

The Marine Strategy Framework Directive (MSFD, 2008/56/EC) establishes a framework for the development of marine strategies designed to achieve Good Ecological Status (GES) in the marine environment, by the year 2020, using 11 qualitative descriptors. The concentration of contaminants including heavy metals in the marine environment and their effects need to be assessed taking into account the impacts and threats to the ecosystem in Article 8(1)(b)(ii) of Directive 2008/56/EC. Contaminants in fish and other seafood for human consumption do not exceed levels established by Community legislation or other relevant standards (Descriptor 9; Directive 2000/60/EC). 
The aims of the study are to determine heavy metals in Pleuronectiformes species from Sinop coasts of the Black Sea and determine the health risks due to the consumption of contaminated fish.

\section{MATERIAL AND METHODS}

In the Turkish Black Sea coasts fish is particularly consumed because of high protein supplies, essential amino acids, vitamin, and mineral content. Fish are exposed to contaminants such as heavy metals in polluted waters. Heavy metals from the anthropogenic activities are continually entered into the marine ecosystem. The Black Sea are contaminated by industrial, domestic and agriculture wastes, metal ions, and organic and inorganic compounds, paints and petroleum products (Bat et al. 2009, Bat et al. 2018b). Heavy metals are major health risks owing to of their toxicity, bioaccumulation, bio-magnifications and long-persistence in the food chain. For example mercury, cadmium and lead are highly toxic and may be reason mental and central nervous system detriment. It is therefore necessary to detect and observe metal amounts in seafood, because metal ions can readily accumulate in fish more than those in other foodstuffs. Non-essential metals are toxic to fish even at very low concentrations, while essential elements become toxic at relatively high concentrations. Heavy metals occur in nature at low concentrations and the increase of their concentration indicates the environmental pollution. Therefore, this study deals with the most important commercial fish species of the Black Sea.

Pleuronectiformes species Scophthalmus maximus (Linnaeus, 1758) belonging to Scophthalmidae family, Arnoglossus laterna (Walbaum, 1792) belonging to Bothidae family and Pegusa lascaris (Risso, 1810) belonging to Soleidae family were collected from Sinop coasts of the Black Sea in fishing season of 2016 (Figure 1). Heavy metals $(\mathrm{Hg}, \mathrm{Cd}$, $\mathrm{Pb}, \mathrm{Cu}$ and $\mathrm{Zn}$ ) in edible tissues were determined by ICP-MS (Agilent 7700x). The sensitivity of the method was made according to the detection limits, which were $<0.001$ $\mu \mathrm{g} / \mathrm{L}$ for $\mathrm{Pb}$ and $\mathrm{Cd},<0.01 \mathrm{Zn}$ and $\mathrm{Hg}$ and $<0.0001 \mu \mathrm{g} / \mathrm{L}$ for $\mathrm{Cu}$. Standard reference material TORT-3 lobster hepatopancreas for metals was used to determine the reliability of the analysis. The daily and weekly intakes of the metals from the consumption of the fish samples were also estimated for adults, and hazard index (HI) in fish samples were calculated to determine the health risks due to the consumption of contaminated fish.

The EDI of metals was determined using the following equation:

$$
\mathrm{EDI}=\mathrm{C} \text { metal } \times \mathrm{W} / \mathrm{b} \text {. wt. }
$$


Where: $\mathrm{C}$ metal is the concentration of metals in fish; $\mathrm{W}$ represents the daily average consumption of fish is given as: $17 \mathrm{~g} /$ day for adults (TUIK, 2016); b. wt. is the body weight of $70 \mathrm{~kg}$ for adults.

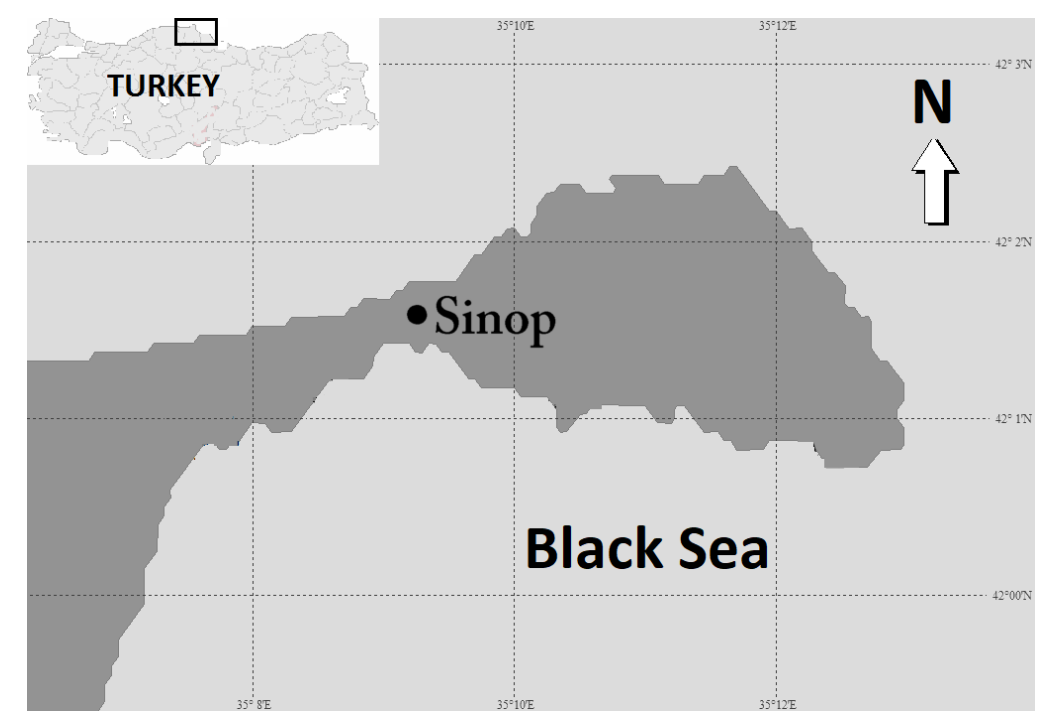

Figure 1. Sampling area

\section{RESULTS}

In the current study, the accuracy of the analytical method in the current work was assessed using the Standard Reference Material TORT-3 lobster hepatopancreas. These standards were treated and analyzed under the same conditions as the samples and recoveries of the metals ranged from 96 to $103 \%$. Determinations of the metals in muscles tissues of 3 commercial Pleuronectiformes fish species from Sinop coasts of the Black Sea were examined. Mean levels with standard deviation of $\mathrm{Hg}, \mathrm{Cd}, \mathrm{Pb}, \mathrm{Cu}$ and $\mathrm{Zn}$ in edible tissues of $S$. maximus, $A$. laterna and $P$. lascaris from Sinop coast of the Black Sea in 2016 were given in Figures 2-6. 
Sustainability, Agri, Food and Environmental Research, (ISSN: 0719-3726), 7(2), 2019: 150-162 http://dx.doi.org/10.7770/safer-VONO-art1664

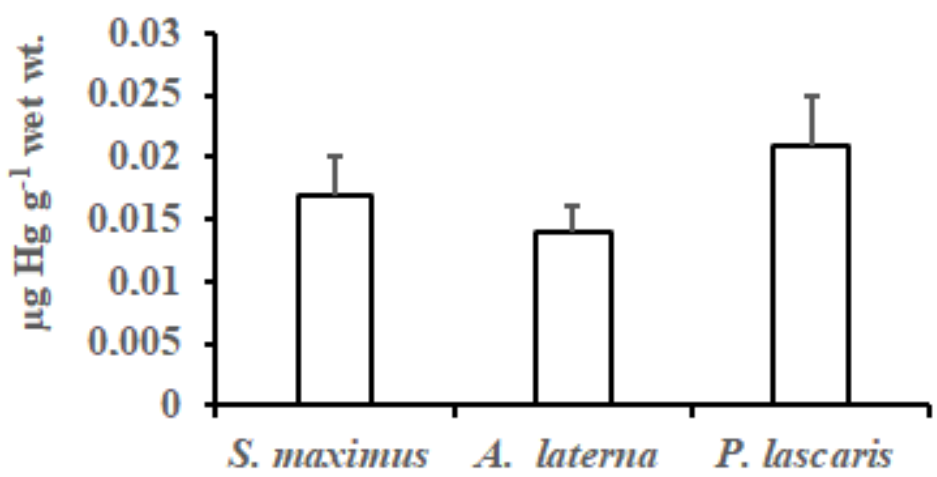

Figure 2. Mean levels with standard deviation of $\mathrm{Hg}$ in the edible tissues of $S$. maximus, A. laterna and P. lascaris from Sinop coast of the Black Sea in 2016.

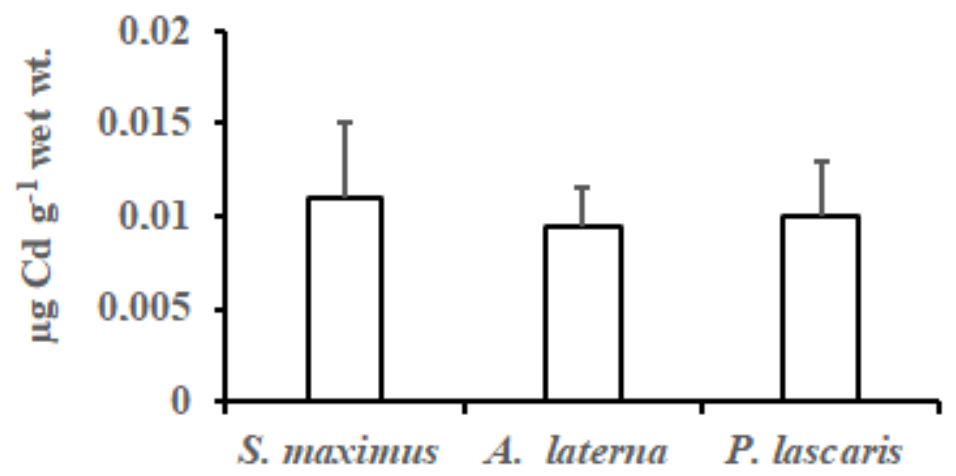

Figure 3. Mean levels with standard deviation of $\mathrm{Cd}$ in the edible tissues of $S$. maximus, A. laterna and $P$. lascaris from Sinop coast of the Black Sea in 2016.

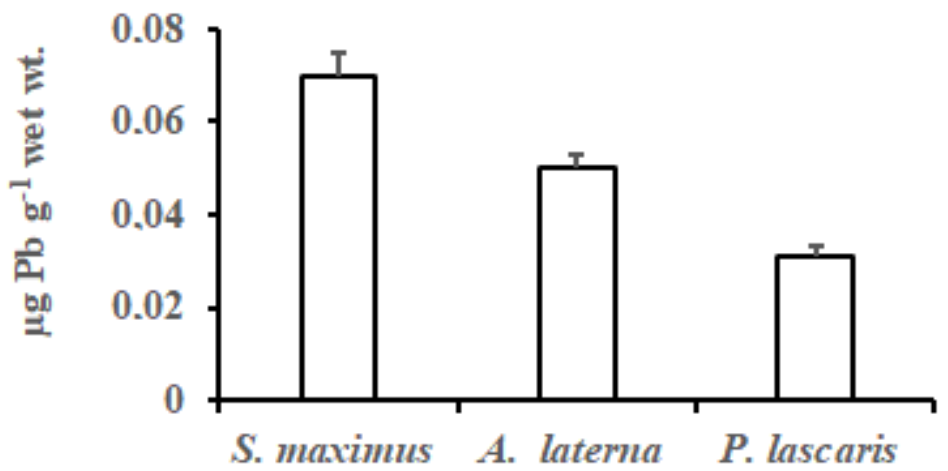

Figure 4. Mean levels with standard deviation of $\mathrm{Pb}$ in the edible tissues of $S$. maximus, A. laterna and P. lascaris from Sinop coast of the Black Sea in 2016. 


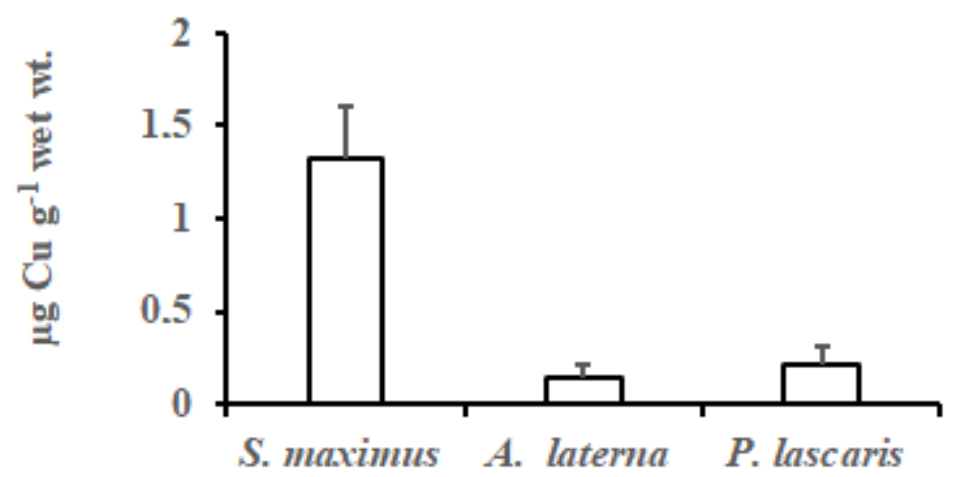

Figure 5. Mean levels with standard deviation of $\mathrm{Cu}$ in the edible tissues of $S$. maximus, $A$. laterna and $P$. lascaris from Sinop coast of the Black Sea in 2016.

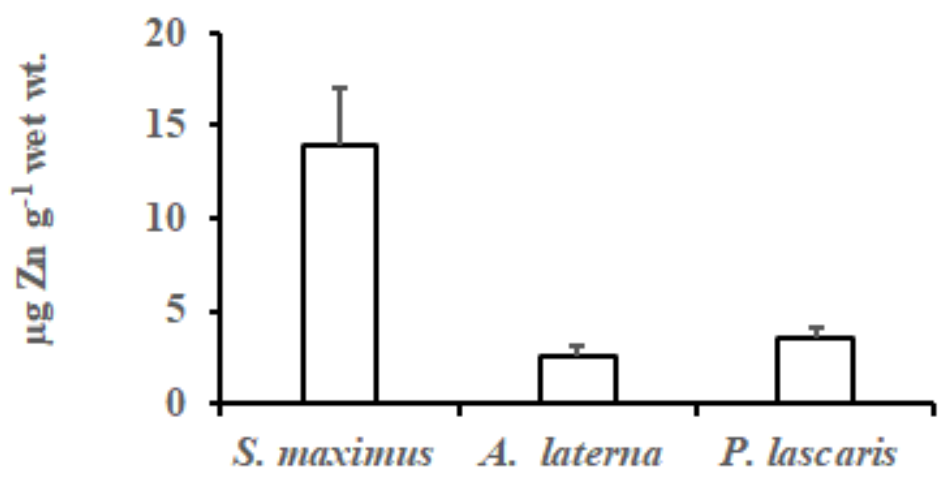

Figure 6. Mean levels with standard deviation of $\mathrm{Zn}$ in the edible tissues of $S$. maximus, A. laterna and P. lascaris from Sinop coast of the Black Sea in 2016.

The results obtained from the analyses of the maximum levels of the metals except $\mathrm{Hg}$ were found in turbot. However, the high amounts of $\mathrm{Cd}, \mathrm{Pb}, \mathrm{Cu}$ and $\mathrm{Zn}$ in turbot were $0.011 \pm 0.004,0.07 \pm 0.005,1.32 \pm 0.28$ and $14 \pm 3 \mu g^{-1}$ wet wt., respectively. This result could be explained with the physiological metabolism of the fish.

\section{DISSCUSSION}

$\mathrm{Cd}$ is a highly toxic element for fish and tends to be accumulated in biota very quickly (Beširović et al., 2010). The European Commission Regulation (EC, 2006) and Turkish Legislation (Turkish Food Codex, 2009 and 2011) determined the maximum

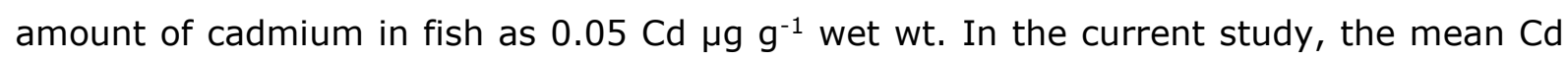
level, obtained for all types of fish was $0.0102 \mathrm{\mu g} \mathrm{g}^{-1}$ wet wt. and this amount did not exceed limit value. Therefore, the consumption of these fish species from Sinop coasts of 
the Black Sea, does not constitute a risk to public health. Similarly, $\mathrm{Hg}$ is very toxic element for biota and seafood including fish is accepted as the main source of it. Regulation of European Commission (EC, 2006) and Turkish Food Codex (TFC, 2009) indicated that the highest concentrations of $\mathrm{Hg}$ could be found in fish as $0.50 \mu \mathrm{g} \mathrm{g}^{-1}$ wet wt. The highest $\mathrm{Hg}\left(0.021 \pm 0.007 \mu \mathrm{g} \mathrm{g}^{-1}\right.$ wet wt.) was found in sand sole. The obtained maximum value was about 24 times lower than permissible limit value, thus species that had been studied could be consumed safely. $\mathrm{Pb}$ is also non-essential element and is a potentially toxic when aquatic organisms such as fish are exposed. The highest level of $\mathrm{Pb}$ obtained in our study was $0.07 \mu \mathrm{g} \mathrm{g}^{-1}$ wet wt. This value was below specified limit, $0.30 \mu \mathrm{g} \mathrm{Pb} \mathrm{g}^{-1}$ wet wt. in fish, specified in European Commission Regulation (EC, 2006) and Turkish Food Codex (TFC, 2009). There is also no risk for people health in consumption of fish species form Sinop coasts of the Black Sea.

Overall $\mathrm{Zn}$ was detected in higher concentrations in all species followed by $\mathrm{Cu}, \mathrm{Pb}$, $\mathrm{Hg}$ and $\mathrm{Cd}$. $\mathrm{Cu}$ is an essential element existing at small amounts in a variety of cells and tissues. However, it is toxic if taken at high levels. The recommended limit value of $\mathrm{Cu}$ is $20 \mu \mathrm{g} \mathrm{Cu} / \mathrm{g}$ wet wt. by MAFF (1995) and TFC (2002). In the current study, the highest mean $\mathrm{Cu}$ concentration was detected as $1.32 \mu \mathrm{g} \mathrm{g}^{-1}$ wet wt. in turbot. The highest $\mathrm{Cu}$ concentration obtained was about 15 times lower than the limit value. $\mathrm{Zn}$ is also an essential element and is considered not to be relatively toxic to humans. Same as $\mathrm{Cu}$, being exposed to very high amounts of $\mathrm{Zn}$ may be toxic effects. According to MAFF (1995) and TFC (2002) recommended limit value of $\mathrm{Zn}$ is $50 \mu \mathrm{g} \mathrm{Cu} / \mathrm{g}$ wet wt. The highest mean $\mathrm{Zn}$ amount was $14 \mu \mathrm{g} \mathrm{g}^{-1}$ wet wt. in turbot. It can be seen that there is not any risk to public health in consumption of these fish species in terms of $\mathrm{Cu}$ and $\mathrm{Zn}$.

In conclusion the limit values given by the international and national organizations did not exceed in the muscle tissues of turbot, Mediterranean scald fish and sand sole. The Estimated Daily Intakes (EDIs) and Estimated Weekly Intakes (EWIs) of the metals were also estimated taking into account the mean of metal in all fish samples and the mean consumption of fish per day/week for adults. Fish having metals could present a pose threat for the consumer which is dependent on the level and amount of fish consumed (Bat 2014). Therefore, the tolerable weekly intakes were estimated by means of references for edible tissues of fishes consumed by people. Fish consumption is approximately to $17 \mathrm{~g}$ /day in 2016 for Turkey (TUIK, 2017). Fish consumption in our coasts including the Black Sea is $25 \mathrm{~kg}$ per capita (Köprücü 2007). Sarıözkan (2016) specified that the mean goal for fish consumption should be $10 \mathrm{~kg} /$ person in Turkey. This value was also used in the study of Bat et al. (2017) and is based on our study.

The tolerable weekly intake of heavy metals as PTWI (Provisional Tolerable Weekly Intake), are set by the Food and Agriculture Organization/World Health 
Organization (FAO/WHO) Joint Expert Committee on Food Additives (JECFA) (FAO/WHO, $2010 ; 2011)$. PTWI is the maximum amount of a contaminant to which a person can be exposed per week over a lifespan without an unacceptable risk of health effects. The estimated daily intake (EDI) and estimated weekly intake (EWI) in this study were calculated by assuming that a $70-\mathrm{kg}$ person will consume $27.4 \mathrm{~g}$ fish/day which is equal to $192 \mathrm{~g}$ fish/week and presented in Table 1 . Intake estimates were expressed as $\mu \mathrm{g} / \mathrm{kg}$ body wt. / daily and weekly.

Table 1. Estimated Weekly Intakes (EWI) and Estimated Daily Intakes (EDI) of heavy metals in edible tissues of commercial Pleuronectiformes species from Sinop coasts of the Black Sea.

\begin{tabular}{|c|c|c|c|c|c|c|}
\hline \multirow{2}{*}{ Metals } & \multirow{2}{*}{ PTWIa } & \multirow{2}{*}{ PTWI $^{\mathrm{b}}$} & \multirow{2}{*}{ PTDI $^{\mathrm{C}}$} & \multicolumn{3}{|c|}{$E W I^{d}(E D I)^{e}$} \\
\hline & & & & S. maximus & A. laterna & P. lascaris \\
\hline \multirow{2}{*}{$\mathrm{Hg}$} & \multirow[t]{2}{*}{4} & \multirow{2}{*}{28} & \multirow{2}{*}{40} & 3.2606 & 2.6852 & 4.0278 \\
\hline & & & & $(0.4658)$ & $(0.3836)$ & $(0.5754)$ \\
\hline \multirow{2}{*}{$\mathrm{Cd}$} & \multirow[t]{2}{*}{7} & \multirow{2}{*}{490} & \multirow{2}{*}{70} & 2.1098 & 1.8222 & $1.918(0.274)$ \\
\hline & & & & $(0.3014)$ & $(0.2603)$ & \\
\hline \multirow{2}{*}{$\mathrm{Pb}$} & \multirow[t]{2}{*}{25} & \multirow{2}{*}{1750} & \multirow{2}{*}{250} & $13.426(1.918)$ & $9.59(1.37)$ & 5.9458 \\
\hline & & & & & & $(0.8494)$ \\
\hline $\mathrm{Cu}$ & 3500 & 245000 & 35000 & $253(36)$ & $26.852(3.836)$ & $42.196(6.028)$ \\
\hline $\mathrm{Zn}$ & 7000 & 490000 & 70000 & $2685(383.6)$ & $498.68(71.24)$ & $671.3(95.9)$ \\
\hline \multicolumn{7}{|c|}{ aPTWI (Provisional Tolerable Weekly Intake) in $\mu \mathrm{g} /$ week/kg body wt. } \\
\hline \multicolumn{7}{|c|}{ bPTWI for $70 \mathrm{~kg}$ adult person ( $\mu \mathrm{g} /$ week/70 kg body wt.) } \\
\hline \multicolumn{7}{|c|}{ CPTDI (Permissible Tolerable Daily Intake) ( $\mu \mathrm{g} /$ day/70 kg body wt.) } \\
\hline \multicolumn{7}{|c|}{ dEWI (Estimated Weekly Intake) ( $\mu \mathrm{g} /$ week/ 70 kg body wt.) } \\
\hline \multicolumn{7}{|c|}{ eEDI (Estimated Daily Intake) ( $\mu \mathrm{g} /$ day/ 70 kg body wt.) } \\
\hline
\end{tabular}

These results are significantly lower than the recommended values of FAO/WHO. Therefore the metals in fish samples do not toxic any apparent threat to the population and these fishes are healthy for consumption. 
Sustainability, Agri, Food and Environmental Research, (ISSN: 0719-3726), 7(2), 2019: 150-162 http://dx.doi.org/10.7770/safer-VONO-art1664

Table 2. Heavy metal concentrations in the edible muscles of Pleuronectiformes species from the Turkish Black Sea coasts (mg/kg)

\begin{tabular}{|c|c|c|c|c|c|c|c|c|}
\hline \multirow{2}{*}{ Species } & \multirow{2}{*}{ Location } & \multirow{2}{*}{$\begin{array}{l}\text { d.w./ } \\
\text { w.w. }\end{array}$} & \multicolumn{5}{|c|}{ Metals } & \multirow{2}{*}{ References } \\
\hline & & & $\mathrm{Hg}$ & $\mathrm{Cd}$ & $\mathrm{Pb}$ & $\mathrm{Cu}$ & $\mathrm{Zn}$ & \\
\hline $\begin{array}{l}\text { Scophthalmus } \\
\text { maximus }\end{array}$ & Sinop & W.W. & $0.017 \pm 0.003$ & $0.011 \pm 0.004$ & $0.07 \pm 0.005$ & $1.32 \pm 0.28$ & $14 \pm 3$ & This study \\
\hline Pegusa lascaris & Sinop & w.w. & $0.021 \pm 0.004$ & $0.01 \pm 0.003$ & $0.031 \pm 0.0025$ & $0.22 \pm 0.09$ & $3.5 \pm 0.6$ & This study \\
\hline Arnoglossus laterna & Sinop & W.W. & $0.014 \pm 0.002$ & $0.0095 \pm 0.002$ & $0.05 \pm 0.003$ & $0.14 \pm 0.07$ & $2.6 \pm 0.5$ & This study \\
\hline $\begin{array}{l}\text { Scopthalmus } \\
\text { maeoticus }\end{array}$ & Sinop & w.w. & $0.065 \pm 0.004$ & $<0.02$ & $<0.05$ & & & Das et al. 2009 \\
\hline $\begin{array}{l}\text { Scopthalmus } \\
\text { maximus }\end{array}$ & Sinop & w.w. & & $<0.02$ & $<0.05$ & 0.54 & & Bat et al. 2017 \\
\hline Psetta maxima & Sinop & d.w. & & 0.27 & 2.72 & 26.14 & 32.93 & Bat et al. 2006 \\
\hline Psetta maxima & Black Sea & w.w & & $0.10 \pm 0.01$ & $0.28 \pm 0.02$ & $0.75 \pm 0.05$ & $45.2 \pm 2.7$ & Tüzen 2009 \\
\hline Psetta maxima & $\begin{array}{l}\text { Samsun, Sinop, } \\
\text { Terme, Fatsa, Ordu }\end{array}$ & d.w. & & 0.02 & 0.73 & 2.13 & 24.83 & Nisbet et al. 2010 \\
\hline Psetta maxima & Black Sea & d.w. & & $0.01 \pm 0.01$ & $0.02 \pm 0.02$ & $0.70 \pm 0.03$ & $21.9 \pm 0.6$ & $\begin{array}{l}\text { Ergül and } \\
\text { Aksan } 2013 \\
\end{array}$ \\
\hline Psetta maxima & Sinop & w.w. & & 0.03 & 0.08 & 0.55 & & Bat and Sezgin 2015 \\
\hline Platichthys flesus & Sinop & w.w. & $<0.05$ & $0.88 \pm 0.01$ & $<0.05$ & & & Das et al. 2009 \\
\hline Solea solea & Black Sea & d.w. & $0.09 \pm 0.02$ & $0.02 \pm 0.01$ & $0.03 \pm 0.01$ & $2.05 \pm 0.06$ & $18.4 \pm 0.6$ & Ergül anD Aksan 2013 \\
\hline Solea solea & Sinop & w.w. & & 0.03 & 0.09 & 0.68 & & Bat and Sezgin 2015 \\
\hline Solea vulgaris & Sinop & d.w. & & 0.22 & 3.571 & 11.58 & 18.03 & Bat et al. 2006 \\
\hline
\end{tabular}


When the heavy metal amounts in Pleuronectiformes Species were compared among the Turkish Black Sea coasts (Table 2), high Hg levels was found to be highest in S. maximus (Ergül and Aksan 2013). Cd and Zn concentrations were found to be highest in S. maximus (Tüzen 2009). $\mathrm{Cu}$ and $\mathrm{Pb}$ values were found to be highest in in S. maximus from Sinop (Bat et al. 2006). If we compared heavy metal levels in Solidae species, maximum $\mathrm{Hg}$ levels were found in S. solea (Ergül and Aksan 2013) and in Pegusa lascaris (this study). The maximum concentrations of $\mathrm{Cd}, \mathrm{Pb}, \mathrm{Cu}$ and $\mathrm{Zn}$ were found in S. vulgaris from Sinop (Bat et al. 2006). Overall, the findings from this study revealed that $\mathrm{Hg}, \mathrm{Cd}, \mathrm{Pb}, \mathrm{Cu}$ and $\mathrm{Zn}$ amounts in the edible tissues were lower than the maximum permissible limit as recommended standards by the Commission Regulation and Turkish Food Codex. It is worth concluded that consumption of these fish from Sinop shores as food may not possible toxic to humans at the time of the study.

\section{ACKNOWLEDGEMENTS}

This work was carried out at the Department of Hydrobiology, Fisheries Faculty, University of Sinop. A part of this study was presented with English abstract only in SEAB 2018, The $4^{\text {th }}$ International Symposium on EuroAsian Biodiversity, Kiev Ukraine.

\section{REFERENCES}

Bat, L., Gündoğdu, A., Yardım, Ö., Zoral, T., and S. Çulha. (2006). Heavy metal amounts in zooplankton and some commercial teleost fish from inner harbour of Sinop, Black Sea. (in Turkish). SUMDER (Journal of Fisheries Engineering), 25: 22-27.

Bat, L., Gökkurt, O., Sezgin, M., Üstün, F., and F. Sahin. (2009). Evaluation of the Black Sea land based sources of pollution the coastal region of Turkey. The Open Marine Biology Journal, 3: 112-124. DOI: 10.2174/1874450800903010112

Bat, L. (2014). Heavy metal pollution in the Black Sea. In: Düzgüneş E, Öztürk B, Zengin M. (Eds.). Turkish Fisheries in the Black Sea. Published by Turkish Marine Research Foundation (TUDAV), Publication number: 40, ISBN: 987-975-8825-32-5 Istanbul, Turkey, p. 71-107.

Bat, L., and Sezgin M., (2015). Heavy metal levels in some commercial fish from Sinop coast of the Black Sea, Turkey, pp. 645-656. Proceedings of the Twelfth International Conference on Mediterranean Coastal Environment MEDCOAST 2015, 06-10 October, Varna, Bulgaria.

Bat, L., and Özkan E.Y., (2015). Chapter 13. Heavy metal levels in sediment of the Turkish Black Sea coast. In: Bikarska I, Raykov V, Nikolov N. (Eds.) Progressive Engineering Practices in Marine Resource Management. IGI Global book series Advances in Environmental Engineering and Green Technologies (AEEGT) (ISSN: 2326-9162; eISSN: 2326-9170) USA, pp. 399-419 
Bat, L. (2017). The Contamination Status of Heavy Metals in Fish from the Black Sea, Turkey and Potential Risks to Human Health. In: Sezgin, M., Bat, L., Ürkmez, D., Arıcı, E., Öztürk, B. (Eds.) Black Sea Marine Environment: The Turkish Shelf. Turkish Marine Research Foundation (TUDAV), Publication No: 46, ISBN- 978-975-8825-38-7, Istanbul, TURKEY, pp. 322-418.

Bat, L., Arici, E., and Ürkmez D., (2017). Heavy metal levels in the Black Sea Sprat (Sprattus sprattus). International Journal of Research in Agriculture and Forestry, 4 (6): 1-8.

Bat, L., and Arıcl, E. (2018). Chapter 5. Heavy Metal Levels in Fish, Molluscs, and Crustacea From Turkish Seas and Potential Risk of Human Health. In: Holban AM, Grumezescu AM. (Eds.) Handbook of Food Bioengineering, Volume 13, Food Quality: Balancing Health and Disease. Elsevier, Academic Press, ISBN: 978-0-12-811442-1, pp. 159-196.

Bat, L., Öztekin, A., Şahin, F., Arıcı, E. and U. Özsandıkçı (2018a). An overview of the Black Sea pollution in Turkey. MedFAR., 1(2): 67-86.

Bat, L., Arici, E. and A. Öztekin. (2018b). Human health risk assessment of heavy metals in the Black Sea: Evaluating Mussels. Current World Environment, 13 (1): 15-31. http://dx.doi.org/10.12944/CWE.13.1.03

Beširović, H., Alic, A., Prasovic, S. and Drommer W., (2010). Histopathological Effects of Chronic Exposure to Cadmium and Zinc on Kidneys and Gills of Brown Trout (Salmo trutta fario) Turkish Journal of Fisheries and Aquatic Sciences, 10: 255-262.

Das, Y.K., Aksoy, A., Baskaya, R., Duyar, H.A., Guvenc, D. and V. Boz. (2009). Heavy metal levels of some marine organisms collected in Samsun and Sinop coasts of Black Sea, in Turkey. Journal of Animal and Veterinary Advances, 8(3): 496-499.

EC (COMMISSION REGULATION) (2001). Setting maximum levels for certain contaminants in foodstuffs, No 466/2001 of 8 March 2001.

EC (COMMISSION REGULATION) (2006). Setting maximum levels for certain contaminants in foodstuffs, No 1881/2006 of 19 December 2006.

Ergül, H.A., and Aksan, S. (2013). Evaluation of non-essential element and micronutrient concentrations in seafood from the Marmara and Black Seas. J. Black Sea/Mediterranean Environment, 19(3): 312-331

FAO/WHO. (2010). Summary report of the seventy-third meeting of JECFA, Joint FAO/WHO Expert Committee on Food Additives, Geneva. 
FAO/WHO. (2011). Joint FAO/WHO food standards programme codex committee on contaminants in foods, Fifth Session, working document for information and use in discussions related to contaminants and toxins in the GSCTFF, The Hague, The Netherlands.

Köprücü, K. (2007), Türkiye su ürünleri üretiminin durumu ve değerlendirilmesi (Status and evaluation of Turkey's aquaculture production). Türk Tarım Dergisi, 178: 22-28 (in Turkish).

MAFF, (1995). Monitoring and surveillance of non-radioactive contaminants in the aquatic environment and activities regulating the disposal of wastes at sea, 1993, Directorate of Fisheries research, Lowestoft, Aquatic Environment Monitoring Report, No.44.

Nisbet, C., Terzi, G., Pilger, O. and Sarac N., (2010). Determination of heavy metal levels in fish sample collected from the Middle Black Sea. Kafkas Univ. Vet. Fak. Der., 16(1): 119125.

Official Journal of the European Union. Directives Directive 2008/56/EC of the European Parliament and of the Council of 17 June 2008 Establishing a Framework for Community Action in the Field of Marine Environmental Policy. Marine Strategy Framework Directive, L 164: 19-40 (2008).

Sarı̈zkan, S. (2016), Türkiye'de balıkçılık sektörü ve ekonomisi (Fishing sector and the economy in Turkey). Turkish Journal of Aquatic Sciences 31(1): 15-22 (in Turkish).

TFC (Turkish Food Codex), (2002), Official Gazette of Republic of Turkey. Notifications about determination of the maximum levels for certain contaminants in foodstuffs of Turkish Food Codex (in Turkish). (Notification No: 2002/63), Issue: 24885.

TFC. (2009). Official Gazette of Republic of Turkey. Notifications changes to the maximum levels for certain contaminants in foodstuffs (in Turkish). (Notification No: 2009/22), Issue: 27143.

TUIK. Turkish Fishery Statistics. (2017) Available online: http://www.tuik.gov.tr/ (visited: $25^{\text {th }}$ May 2018)

Tuzen, M. (2009). Toxic and essential trace elemental contents in fish species from the Black Sea, Turkey. Food and Chemical Toxicology, 47: 1785-1790. 